\title{
With or Without a Computer? Do You Want to Play with Me?
}

\author{
Abílio Oliveira \\ Instituto Universitário de Lisboa (ISCTE-IUL), and Centro de Investigação em Sistemas \\ e Tecnologias de Informação Avançados (ADETTI-IUL), Lisboa, Portugal. \\ Author of several books (abiliooliveira.weebly.com) \\ Email: abilio.oliveira@iscte.pt
}

\section{Ricardo Dias}

Elementary School Teacher at Ministry of Education, and Researcher at Education Sciences, Lisboa, Portugal.

\section{Doi:10.5901/mjss.2014.v5n13p21}

\section{Abstract}

The new technologies are increasingly crucial in all areas. The computer and other technological devices, the communication and information systems, can bring us great benefits, facilitating and streamlining many of our common tasks and activities. We highlight the importance of computer in learning and, particularly, in leisure/recreational activities. In what extent children prefer to play, and communicate, via computer, tablet or other device? Do they easily dispense technological means, choosing to play in social interaction and direct contact? Do they prefer to be at home, at school, at the park or in another natural environment? We intend to verify the importance that children attribute to the computer and how they like to use it, either in the context of learning, retrieving information, doing homework, or in recreational terms. The major objective of this work is to verify to what extent the computer is important in the personal, emotional and social development of children, by the way they use it in their duties, games and daily interactions. We conducted an exploratory study with a population of boys and girls, attending the first four years of schooling. Data were collected within the scope of focus groups and individual interviews. Most children consider that the computer is significant both in study as in the interaction with friends, and many prefer to be online, playing games or exploring virtual worlds, than being offline, doing any sport, talking or hanging out with friends, in outdoor activities. The way children represent and use the computer, help us to better understand the risks they run and the benefits that virtual worlds offer.

Keywords: Children, computer, internet, playing, learning, information, social networks, social interaction, games.

\section{Introduction}

Nowadays, children use the computer as an essential tool for their well-being and fun, navigating in virtual worlds with ease and practical sense, in search of knowledge, emotions and experiences.

What we want here is to assess whether children prefer a life in contact with nature, with other children and without a computer, or if on the other hand, prefer to spend all the time they can in front of a computer, searching for information or participating in online games, many times with violent or inappropriate contents for their age group, running various risks, particularly in social networks.

The way children look at the computer and what it relates to this machine, may help us to better understand both the risks children run as well as the benefits that virtual worlds can provide them, and the reason for their choice.

Panqueva (1997) argues that, contrary to what many educators think, fun is not childish. Between six and twelve years old children are in the middle of their cognitive, personal and social development (e.g. Oliveira, 2008). They are very curious with the modern information and communication technologies that surround them. Sometimes we can even speak of an obsession of children which reveal an extra motivation for the use of computers, consoles, tablets, mobiles and other objects of technological nature.

The traditional model of education, centered in the figure of the teacher - responsible for the transmission of knowledge to the student - despite fulfill their role, it is unlikely that it can form professionals which may be able to respond to all the challenges in the new global scenario (Kuri, 1998). It is up to us adults, the task of guiding the use of the computer and assures that children are using it in an assertive way. 


\subsection{School in Portugal}

Since a long time the role of the school is no longer a mere transmitter of knowledge. Today, it is imperative that students realize what means to learn, being more independent, learning to apply the knowledge in new contexts, and developing a love of learning. Educating is more than imparting knowledge: we must teach students the way how they can learn, in order they may feel prepared for a lifetime of learning (Harb et al., 1991).

Students should regard the school as a place where they can learn and acquire skills in order to develop adequate competences in social, personal and cognitive terms. The school should be the place where students, with teacher's assistance, can build their knowledge and acquire new skills, becoming increasingly independent. Nowadays, children have access to all kinds of information and the truth is that is through technological means that they can search for everything they want or about what they feel curiosity. Thus, the teacher must have to open the classroom to new technologies, making the teaching process more interactive, attractive and interesting for their students, fostering their interests and preferences.

Computer use in the classroom should be seen as a very important aid for the cognitive development of students, without exceeding the teacher's role. The computer allows the use of educational methods more dynamic, interactive and attractive, arousing in the students the desire to seek for diverse information, and to participate effectively on their own process of teaching and learning (Lima, 1996).

\subsection{E-learning}

Distance education constitutes a paradigm shift compared to traditional classroom education. Students and teachers also have to make changes in their roles. The responsibility of the students about their learning, increases, and it require a more active stance. Meanwhile, teachers become facilitators of the process, by ensuring conditions for students to achieve their goals.

In distance education, with or without some classroom time, students usually are part of a heterogeneous group that may be dispersed, in geographical and temporal terms, with students living with different economic, social and cultural situations (Scapin, 1997 ). The capacity of learning and the knowledge of each student may also differ. The teacher has to know and respect these differences. A problem often stems from the fact that students are accustomed to classroom teaching, and can feel great difficulty in studying from their own individual effort. But the teacher can foster motivation and help students develop skills involving independence and initiative.

A system of distance education success involves the interaction between teachers and students, between students and the learning environment, and between students themselves. However, distance education cannot be seen as a substitute for traditional classroom education (Nunes, 1994). Both forms of education are needed, and when combined, they complement each other to provide better results (e.g. Moran, 1994).

\section{Objective}

The main objective of this study was to evaluate to what extent the computer is important in social and emotional development of children (playful part of children's life).

\section{Method}

We conducted an exploratory study with a population of fifteen boys and girls, between nine and twelve years old, attending the first four years of schooling. Data were collected within the scope of two focus groups and individual interviews.

Some of the questions under discussion were the following:

- If you have the opportunity to choose, do you rather play with friends on the computer, or without a computer in direct/personal contact?

- If you are in direct contact with colleagues/friends, do you prefer to be at home, in the street, in the park, in the playground, in the garden or another natural environment... where...?

- Do you prefer to play on the computer, tablet, cell phone, playstation or other electronic device?

- Do you usually play online? How often?

- Do you prefer to chat/talk/communicate with friends directly (in person) or through a computer, tablet, cell phone, playstation or other device? 
- What are the software/programs you use to communicate with others through the computer (facebook, skype, google, etc)?

- Could you dispense the usual technological means, in your day-to-day, preferring instead to play or interact (directly) with your colleagues/friends?

- Do you prefer to be on the computer or being in contact with nature (eventually, walking in a natural ambient)?

- Would you rather be alone on the computer or with someone else?

- If you are accompanied, who would you choose to be with you?

- And who sits with you, more often, on the computer?

- How do you use the computer? To play, study, watch videos, conduct research, or...?

- How much time do you spend on average, daily, on the computer? Alone or accompanied? If accompanied, then, by whom?

- Do you like to study and do homework on the computer?

- To what extent do you think the computer will help you learn?

- What represents the computer for you?

- Can you easily imagine yourself living without using the computer regularly?

- Do you have a cell phone?

- Do you have net access and do you surf the net with your cell phone?

Next, we will focus our attention particularly in some of these questions.

\section{Main Results}

After analyzing and categorizing all responses, in terms of thoughts, ideas and opinions expressed by the participants in this focus group $(N=15)$, we established the main categories or dimensions resulting from these analyses. The findings for these dimensions are summarized on Tables 1 to 18. In each table, we show the main subcategories we have found for the respective category or dimension, the results within each subcategory - in terms of frequency and percentage and also the results obtained according to the sexual group or gender (boys $\hat{\sigma}$ and girls + ).

Table 1 - Main sub-categories associated to the category/dimension

If you have the opportunity to choose, do you rather play with friends on the computer, or without a computer - in direct/personal contact?

\begin{tabular}{|c|c|c|c|c|c|c|c|}
\hline & \multicolumn{2}{|c|}{ Play without computer } & \multicolumn{2}{|c|}{ Play with computer } & \multicolumn{2}{|c|}{ Play with friends } & Totals \\
\hline$\hat{\sigma}$ & 2 & $13 \%$ & 4 & $27 \%$ & 1 & $7 \%$ & $47 \%$ \\
\hline 오 & 3 & $20 \%$ & 2 & $13 \%$ & 3 & $20 \%$ & $53 \%$ \\
\hline Totals & 5 & $33 \%$ & 6 & $40 \%$ & 4 & $27 \%$ & $100 \%$ \\
\hline
\end{tabular}

Many children prefer to play on the computer - whether they play alone or play with some friend - than play with friends, offline (cf. Table 1). In this respect, girls differ from boys because they give greater importance than boys, to be with friends, and play with them. Boys, in particular, give greater emphasis to the computer and do not disassociate this machine from his playful side, associated with several games, both those playing online, in interaction with other players, as to other types of games. When speaking with these young people, we easily verify that the entertainment component is undoubtedly the one to which the boys give a stronger importance. However, when faced with the possibility of playing without a computer, young people prefer to be on the street or play in the park with friends rather than staying at home or going out in the garden (cf. Table 2).

Table 2 - Main sub-categories associated to the category/dimension

If you are in direct contact with colleagues/friends, do you prefer to be at home, in the street, in the park, in the playground, in the garden or another natural environment?...

\begin{tabular}{c|c|c|c|c|c|c|c|c|c}
\cline { 2 - 9 } \multicolumn{2}{c}{ Being home } & \multicolumn{2}{c|}{ Being on the street } & \multicolumn{2}{c|}{ In the park } & \multicolumn{2}{c|}{ In the garden } & Totals (\%) \\
\hline$\delta$ & 1 & $7 \%$ & 4 & $27 \%$ & 2 & $13 \%$ & 1 & $7 \%$ & $54 \%$ \\
\hline \hline & 2 & $13 \%$ & 1 & $7 \%$ & 2 & $13 \%$ & 2 & $13 \%$ & $46 \%$ \\
\hline Totals & 3 & $20 \%$ & 5 & $34 \%$ & 4 & $26 \%$ & 3 & $20 \%$ & $100 \%$ \\
\hline
\end{tabular}


The children who like to spend more time at home, they wish, where possible, use the computer - or rather the playstation, in the case of boys - to play all kind of games (cf. Table 3). From our group conversation with these children, also stressed out the pleasure for playing online - games which are often war games, strategy games, platforms or sports. Girls tend to choose lighter games than boys, and they use the tablet more often than boys do. These results also lead us to admit that most students usually are alone when they play on the computer. About half of the students referred they just play on the weekend. It is clear that boys like to play more than girls - preferably every day, if they can. In fact, there is only one boy who says he does not usually play online, but we do not find any girl who admits to play every day (cf. Table 4).

Table 3 - Main sub-categories associated to the category/dimension

Do you prefer to play on the computer, tablet, playstation, cell phone or other electronic device?

\begin{tabular}{c|c|c|c|c|c|c|c}
\cline { 2 - 7 } \multicolumn{2}{c}{ Playstation } & \multicolumn{2}{c|}{ Computer } & \multicolumn{2}{c|}{ Tablet } & Totals (\%) \\
\hline$\delta$ & 5 & $34 \%$ & 2 & $13 \%$ & - & - & $47 \%$ \\
\hline$\phi$ & 2 & $13 \%$ & 4 & $27 \%$ & 2 & $13 \%$ & $53 \%$ \\
\hline Totals & 7 & $47 \%$ & 6 & $40 \%$ & 2 & $13 \%$ & $100 \%$ \\
\hline
\end{tabular}

Table 4 - Main sub-categories associated to the category/dimension Do you usually play online? How often?

\begin{tabular}{c|c|c|c|c|c|c|c|c|c}
\cline { 2 - 10 } & \multicolumn{2}{c}{$1 \times /$ week } & \multicolumn{2}{c|}{ Weekend } & \multicolumn{2}{c|}{ Everyday } & \multicolumn{2}{c}{ No } & Totals (\%) \\
\hline$\delta$ & - & - & 3 & $20 \%$ & 3 & $20 \%$ & 1 & $7 \%$ & $47 \%$ \\
\hline$q$ & 1 & $6 \%$ & 4 & $27 \%$ & - & - & 3 & $20 \%$ & $53 \%$ \\
\hline Totals & 1 & $6 \%$ & 7 & $47 \%$ & 3 & $20 \%$ & 4 & $27 \%$ & $100 \%$ \\
\hline
\end{tabular}

Girls prefer, clearly, speak personally with their friends, while boys prefer to use the computer, particularly Facebook, to chat with friends. Girls, more than boys, favor direct contact with friends. face to face, or through a video chat. If girls are using the computer also like to use Google, with frequency, and Skype (cf. Tables 5, 6).

Table 5 - Main sub-categories associated to the category/dimension

Do you prefer to chat/talk/communicate with friends directly (in person) or through a computer, tablet, cell phone, playstation or other device?

\begin{tabular}{c|c|c|c|c|c}
\cline { 2 - 6 } \multicolumn{2}{c|}{ Talk in person } & \multicolumn{2}{c|}{ Computer } & Totals (\%) \\
\hline 0 & 2 & $13 \%$ & 6 & $40 \%$ & $53 \%$ \\
\hline$q$ & 5 & $34 \%$ & 2 & $13 \%$ & $47 \%$ \\
\hline Totals & 7 & $47 \%$ & 8 & $53 \%$ & $100 \%$ \\
\hline
\end{tabular}

Table 6 - Main sub-categories associated to the category/dimension

What is the software/programs you use to communicate with others through the computer (Facebook, Skype, Google, etc)?

\begin{tabular}{c|c|c|c|c|c|c|c}
\cline { 2 - 7 } & \multicolumn{2}{c|}{ Facebook } & \multicolumn{2}{c|}{ Google } & \multicolumn{2}{c|}{ Skype } & Totals (\%) \\
\hline 0 & 4 & $27 \%$ & 2 & $13 \%$ & 1 & $7 \%$ & $47 \%$ \\
\hline$q$ & 2 & $13 \%$ & 4 & $27 \%$ & 2 & $13 \%$ & $53 \%$ \\
\hline Totals & 6 & $40 \%$ & 6 & $40 \%$ & 3 & $20 \%$ & $100 \%$ \\
\hline
\end{tabular}

Children, especially boys, reveal a sort of dependence on the computer and technological means, not dismissing these means in their day-to-day, unlike girls. Girls prefer touring or being in contact with nature - preferably with some friends than staying home to play online (cf. Tables 7, 8). 
Table 7 - Main sub-categories associated to the category/dimension

Could you dispense the usual technological means, in your day-to-day, preferring instead to play or interact (directly) with your colleagues/friends?

\begin{tabular}{c|c|c|c|c|c|c|c}
\cline { 2 - 7 } \multicolumn{2}{c|}{ Yes } & \multicolumn{2}{c|}{ No } & \multicolumn{2}{c|}{ Maybe } & Totals (\%) \\
\hline 0 & - & - & 6 & $40 \%$ & 1 & $7 \%$ & $47 \%$ \\
\hline+ & 3 & $20 \%$ & 5 & $33 \%$ & - & - & $53 \%$ \\
\hline Totals & 3 & $20 \%$ & 11 & $73 \%$ & 1 & $7 \%$ & $100 \%$ \\
\hline
\end{tabular}

Table 8 - Main sub-categories associated to the category/dimension

Do you prefer to be on the computer or being in contact with nature (eventually, walking in a natural ambient)?

\begin{tabular}{c|c|c|c|c|c|c|c}
\cline { 2 - 7 } \multicolumn{2}{c|}{ Play on computer } & \multicolumn{2}{c|}{ Being in touch with nature } & \multicolumn{2}{|c|}{ Wander } & Totals (\%) \\
\hline$\hat{0}$ & 5 & $33 \%$ & 1 & $7 \%$ & 1 & $7 \%$ & $47 \%$ \\
\hline+ & 2 & $13 \%$ & 2 & $13 \%$ & 4 & $27 \%$ & $53 \%$ \\
\hline Totals & 7 & $46 \%$ & 3 & $20 \%$ & 5 & $34 \%$ & $100 \%$ \\
\hline
\end{tabular}

In relation to the boys we spoke to, all like to be alone on the computer. Rather, most girls like to stay accompanied. When we ask them to tell us whom they prefer to stay, they answer they like to be with the father or mother; their siblings are also a good alternative (cf. Tables 9, 10).

Table 9 - Main sub-categories associated to the category/dimension Would you rather be alone on the computer or with someone else?

\begin{tabular}{c|c|c|c|c|c}
\cline { 2 - 6 } \multicolumn{2}{c|}{ Alone } & \multicolumn{2}{c|}{ Accompanied } & Totals (\%) \\
\hline 0 & 7 & $46 \%$ & - & - & $46 \%$ \\
\hline$\rho$ & 3 & $20 \%$ & 5 & $34 \%$ & $54 \%$ \\
\hline Totals & 10 & $66 \%$ & 5 & $34 \%$ & $100 \%$ \\
\hline
\end{tabular}

Table 10 - Main sub-categories associated to the category/dimension And who sits with you, more often, on the computer?

\begin{tabular}{c|c|c|c|c|c|c|c|c|c}
\cline { 2 - 9 } \multicolumn{2}{c}{ Father/Mother } & \multicolumn{2}{c|}{ Brother/Sister } & \multicolumn{2}{c|}{ Cousin } & \multicolumn{2}{c|}{ Grandfather } & Totals (\%) \\
\hline 0 & 3 & $20 \%$ & 3 & $20 \%$ & 1 & $7 \%$ & - & - & $47 \%$ \\
\hline+ & 5 & $33 \%$ & 2 & $13 \%$ & - & - & 1 & $7 \%$ & $53 \%$ \\
\hline Totals & 8 & $53 \%$ & 5 & $33 \%$ & 1 & $7 \%$ & 1 & $7 \%$ & $100 \%$ \\
\hline
\end{tabular}

As already noticed, the boys want to use the computer mainly to play. Instead, most girls like to use the computer principally to study, in benefit of their learning process. However, the majority of young people in our sample agree that the computer really helps to learn, so they like to study, search for information and do the homework with the computer. However are the girls who best recognize the significant role of the computer in the process of teaching and learning (cf. Tables 11, 12, 13, 14).

Table 11 - Main sub-categories associated to the category/dimension How do you use the computer? To play, study, watch videos, research, or...?

\begin{tabular}{c|c|c|c|c|c|c|c}
\cline { 2 - 7 } \multicolumn{2}{c|}{ Play } & \multicolumn{2}{c|}{ Study } & \multicolumn{2}{c}{ Everything } & Totals (\%) \\
\hline 0 & 6 & $40 \%$ & - & - & 1 & $7 \%$ & $47 \%$ \\
\hline+ & 3 & $20 \%$ & 5 & $33 \%$ & - & - & $53 \%$ \\
\hline Totals & 9 & $60 \%$ & 5 & $33 \%$ & 1 & $7 \%$ & $100 \%$ \\
\hline
\end{tabular}


Table 12 - Main sub-categories associated to the category/dimension To what extent do you think the computer will help you learn?

\begin{tabular}{|c|c|c|c|c|c|c|c|c|c|}
\hline & \multicolumn{2}{|c|}{$\begin{array}{l}\text { Help me to learn } \\
\text { everything }\end{array}$} & \multicolumn{2}{|c|}{$\begin{array}{l}\text { Help me to search for } \\
\text { information }\end{array}$} & \multicolumn{2}{|c|}{$\begin{array}{l}\text { Help me on } \\
\text { homework }\end{array}$} & \multicolumn{2}{|c|}{$\begin{array}{c}\text { Does not } \\
\text { help }\end{array}$} & \multirow{2}{*}{$\begin{array}{c}\begin{array}{c}\text { Totals } \\
(\%)\end{array} \\
47 \%\end{array}$} \\
\hline$\pi$ & 5 & $33 \%$ & 2 & $13 \%$ & - & - & - & - & \\
\hline q & 5 & $33 \%$ & 1 & $7 \%$ & 1 & $7 \%$ & 1 & $7 \%$ & $54 \%$ \\
\hline Totals & 10 & $66 \%$ & 3 & $20 \%$ & 1 & $7 \%$ & 1 & $7 \%$ & $100 \%$ \\
\hline
\end{tabular}

Table 13 - Main sub-categories associated to the category/dimension What represents the computer for you?

\begin{tabular}{c|c|c|c|c|c|c|c|c|c|c|c}
\cline { 2 - 11 } \multicolumn{2}{c|}{ Search } & \multicolumn{2}{c|}{ Play } & \multicolumn{2}{c|}{ Learn } & \multicolumn{2}{c|}{ Study } & \multicolumn{2}{|c|}{ Life } & Totals (\%) \\
\hline$\hat{0}$ & 2 & $13 \%$ & 5 & $33 \%$ & - & - & - & - & - & - & $46 \%$ \\
\hline+ & - & - & 2 & $13 \%$ & 4 & $27 \%$ & 1 & $7 \%$ & 1 & $7 \%$ & $54 \%$ \\
\hline Totals & 2 & $13 \%$ & 7 & $46 \%$ & 4 & $27 \%$ & 1 & $7 \%$ & 1 & $7 \%$ & $100 \%$ \\
\hline
\end{tabular}

Table 14 - Main sub-categories associated to the category/dimension Do you like to study and do homework on the computer?

\begin{tabular}{c|c|c|c}
\cline { 2 - 4 } \multicolumn{2}{c|}{ Yes } & Totals (\%) \\
\hline 0 & 7 & $46 \%$ & $46 \%$ \\
\hline$q$ & 8 & $54 \%$ & $54 \%$ \\
\hline Totals & 15 & $100 \%$ & $100 \%$ \\
\hline
\end{tabular}

In accordance with what has already been determined (cf. Table 7), the boys seem to depend more on the computer than girls, because no boy can imagine to live without a cybernetic machine. In any case, $80 \%$ of our young respondents make use of the computer, on average, one hour per day, and would have difficulty living without being able to use regularly (cf. Tables 15, 16).

Table 15 - Main sub-categories associated to the category/dimension Can you easily imagine yourself living without using the computer regularly?

\begin{tabular}{c|c|c|c|c|c}
\cline { 2 - 5 } \multicolumn{2}{c|}{ Yes } & \multicolumn{2}{c|}{ No } & Totals (\%) \\
\hline 0 & - & - & 7 & $46 \%$ & $46 \%$ \\
\hline+ & 3 & $20 \%$ & 5 & $34 \%$ & $54 \%$ \\
\hline Totals & 3 & $20 \%$ & 12 & $80 \%$ & $100 \%$ \\
\hline
\end{tabular}

Table 16 - Main sub-categories associated to the category/dimension How much time do you spend on average, daily, on the computer?

\begin{tabular}{c|c|c|c|c|c|c|c|c|c}
\cline { 2 - 9 } & \multicolumn{2}{c|}{$30 \mathrm{~m} / \mathrm{day}$} & \multicolumn{2}{c|}{ 1h/day } & \multicolumn{2}{c|}{ 1h30m/day } & \multicolumn{2}{c}{ Just on weekend } & Totals (\%) \\
\hline$\delta$ & 3 & $20 \%$ & 4 & $26 \%$ & 1 & $7 \%$ & & & $54 \%$ \\
\hline$q$ & 1 & $7 \%$ & 4 & $26 \%$ & 1 & $7 \%$ & 1 & $7 \%$ & $53 \%$ \\
\hline Totals & 4 & $27 \%$ & 8 & $52 \%$ & 2 & $14 \%$ & 1 & $7 \%$ & $100 \%$ \\
\hline
\end{tabular}

Finally, it should be added that most of these children have a mobile phone and uses that technology frequently to access the Internet and social networks (cf. Tables 17, 18).

Table 17 - Main sub-categories associated to the category/dimension Do you have a cell phone?

\begin{tabular}{c|c|c|c|c|c}
\cline { 2 - 5 } \multicolumn{2}{c|}{} & \multicolumn{2}{c|}{ Yes } & Totals (\%) \\
\hline$\sigma$ & 6 & $40 \%$ & 1 & $7 \%$ & $47 \%$ \\
\hline$\phi$ & 3 & $20 \%$ & 5 & $33 \%$ & $53 \%$ \\
\hline Totals & 9 & $60 \%$ & 6 & $40 \%$ & $100 \%$ \\
\hline
\end{tabular}


Table 18 - Main sub-categories associated to the category/dimension Do you surf the net through your cell phone?

\begin{tabular}{c|c|c|c|c|c}
\cline { 2 - 6 } \multicolumn{2}{c|}{ Yes } & \multicolumn{2}{c|}{ No } & Totals (\%) \\
\hline$\sigma$ & 6 & $40 \%$ & 1 & $7 \%$ & $47 \%$ \\
\hline$\phi$ & 1 & $7 \%$ & 7 & $46 \%$ & $53 \%$ \\
\hline Totals & 7 & $47 \%$ & 6 & $53 \%$ & $100 \%$ \\
\hline
\end{tabular}

\section{Discussion and Conclusion}

Technology is everywhere and in almost everything. Nowadays we barely could survive without technologies, information and telecommunication. In fact, over time, computer use became increasingly common. It is something with who we have to live in the most diverse contexts, situations and circumstances Through the Internet, we can transcend the physical space, meet and talk with people far away without leaving home, writing text with moving images and peculiar sounds, look to an infinite range of photos, draw and at the same time, listening to music or watching videos, shopping, establish relationships in virtual communities, participate in chats, consult the bank statement, pay bills, ... or simply read some news in real time. Anyway, work and play are mixed up in cyberspace.

The computer is present in the lives of modern child and can sometimes affect the construction of their identity. In the beginning, the child sees the computer primarily as something that allows you to play and have fun. Over time, and as his identity is developing, the child look at the computer as an important resource for their learning and as an essential working tool, in the near future.

The technologies and computers can greatly foster the process of teaching and learning. The problem in Portugal is that the introduction of computers in education has generated resistance and created controversies that undermine the proper introduction of these means, and the possible beneficial consequences, in terms of education (e.g. Almeida, 2001; Mercado, 2002; Moraes, 2000; Oliveira, 2008; Valente, 1993). Initially some teachers felt insecure, not only by the need to adapt to new situations and invest in their training, but also by the fear of being replaced by machines.

However, there has been an effort integrate and generalize, in the classroom (in addition to the traditional means of teaching), the use of IT tools, educational software, audiovisual and multimedia technologies, and virtual platforms using e-learning - in order to improve conditions of education and provide students with good learning conditions, raising their attention and autonomy. The teacher's role is also to relearn how to learn, and change qualitatively. More than an expert in the learning process, the teacher should encourage the development of skills, skills, intelligence, attitudes and values.

In this study we found that children enjoy using the computer and feel more motivated to learn when the computer is part of their daily lives. Between 9 and 12 years old, children very often use the computer with entertainment purposes (playing online, browsing through social networks, viewing videos and photos), and most of the time they are alone and with no adult support.

Indeed, all young people interviewed by us, use computers in different situations, namely to do their homework. However, while boys overestimate the playful function of the computer, and the computer as a tool to play online (with other friends with whom they communicate online, frequently through Facebook), girls prefer, when possible, have a direct or personal contact with friends, enjoying the opportunity to walk and be in contact with nature, using the computer, preferably to make some research for information and to study (targeting their learning). Most consider that could not live well without a computer, and this is much more noticeable, particularly, in the case of boys. Socialization is also increasingly done through virtual means, with all the implications that might ensue.

We all need to become more attentive to the signs of the times, as fathers and as teachers. Future teachers may undertake specific training in order to know how to correctly use all the potential that a computer has. They can thus better monitor their students and make teaching and learning more engaging and interactive, helping the children in their development.

\section{References}

Almeida, M. (2000). Informática e Formação de Professores. Brasília: Ministério da Educação.

Gonçalves, C. (1996). Quem tem medo do ensino à distância. Revista Educação à Distância, n.7/8, Acessed in May 25, 2014, in http://www.intelecto.net/ead/consuelo.html.

Harb, J. et al. (1991). Teaching through the cycle: Application of Learning Style Theory to Engineering Education at Brigham Young University. Brigham: Brigham Young University Press. 
Kuri, N. (1998). Ciclo de Aprendizagem: uma estratégia para o Planejamento do ensino-aprendizagem. Trabalho digitado da disciplina SEP-5734 "Sistemas Especialistas Tutores", do Programa de Pós-Graduação em Engenharia de Produção. São Paulo: Escola de Engenharia de São Carlos - Universidade de São Paulo.

Lima, R. (1996). A utilização de sistemas multímida na educação e treinamento: uma aplicação em MRPII. Dissertação de Mestrado. São Paulo: Escola de Engenharia de São Carlos - Universidade de São Paulo.

Mercado, L. (2002). Novas tecnologias na educação: refelexão sobre a prática. Maceió: Edufal.

Moraes, R. (2000). Informática na educação. Rio de Janeiro: DPA.

Moran, J. (1994). Novos caminhos no ensino à distância. Informe CEAD, ano 1, 5, 1-3, Acessed in May 25, 2014, in http://www.eca.usp.br/teste/profmoran/distanci.htm.

Nunes, I. (1994). Noções de educação à distância. Revista Educação à distância, n.4/5, p.7-25. http://www.intecto.net/ead/ivonio1.html $(29 / 05 / 00)$

Oliveira. A. (2008). Ilusões na Idade das Emoções. Lisboa: F.C.T./F.C.G..

Panqueva, A. (1997). 'Software educativo multímidia: aspectos críticos no seu ciclo de vida'. Revista de Ensino de Engenharia, 1, 9-18, set.

Scapin, R. (1997). Desenvolvimento de uma ferramenta para criação e correção automáticas de provas na world-wide-web. Dissertação de Mestrado. São Paulo: Escola de Engenharia de São Carlos - Universidade de São Paulo.

Sherry, L. (1995). 'Issues in distance learning'. International Journal of Educational Telecommunications, v.1, n.4, 337-365, Acessed in May 25, 2014, in http://www.cudenver.edu/sherry/pubs/issues.html.

Valente, J. (1993). Computadores e conhecimento: repensando a educação. Campinas: Gráfica Central de Unicam. 